PRÁVNE ROZPRAVY ON-SCREEN II. - Sekcia súkromného práva

online vedecká konferencia - 13. november 2020

ZODPOVEDNOSŤ ZA FAKTICKÉ VADY V RÍMSKEJ KÚPNO-

PREDAJNEJ ZMLUVE

LIABILITY FOR DEFECTS IN ROMAN CONTRACT OF SALE

Michal Turošík ${ }^{1}$

DOI: https://doi.org/10.24040/pros.13.11.2020.ssp.191-201

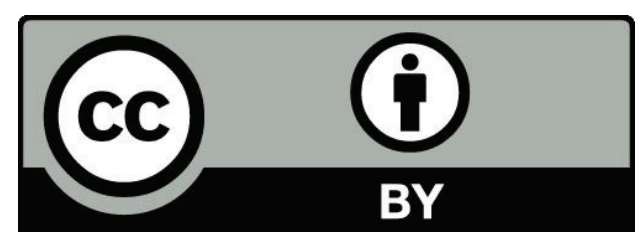

\begin{abstract}
Abstrakt
Nasledovný príspevok sa bude zaoberat' zodpovednostou, ktorú musel znášat' predávajúci v rímskom práve za faktické vady na predmete kúpy. Rímska zodpovednost’ bola koncipovaná pomerne prísne, čoho dôkazom je identifikácia viacerých samostatných žalôb, ktoré mali slúžit’ ako právna ochrana kupujúceho. Aj na tomto základe sa neskôr v moderných právnych poriadkoch vyvinula ochrana kupujúceho limitovaná nielen obsahom, ale aj časom ako účinný prostriedok pred zneuživaním dominantného postavenia na trhu.
\end{abstract}

\title{
Kl'účové slová
}

Zmluva. Kúpa. Vada. Predávajúci. Kupujúci.

\begin{abstract}
The following article will deal with the liability that the seller had to have in roman law for factual defects in the subject of purchase. Roman liability was conceived relatively strictly, as were evidenced by the identification of a number of separate actions which were intended to serve as legal protection for the buyer. Also on this basis, in modern legal systems, the protection of the buyer was limited, not only by the content, but also by time as an effective tools against the abuse of a dominant position on the market.
\end{abstract}

Key words

Contract. Purchase. Defect. Seller. Buyer.

Pokial' sa jedná o charakteristiku faktických vád, ide o nedostatky na predmete kúpy, ktoré obmedzujú jeho užívanie tým, že je znížená jeho úžitková hodnota. Objekt kúpy tu nie je možné použivat' spôsobom, ktorý bol deklarovaný alebo spôsobom, ktorý je možné v bežných prípadoch od takýchto vecí očakávat', prípadne jeho vlastnosti nezodpovedajú tým,

\footnotetext{
${ }^{1}$ doc. Dr. iur. JUDr. Ing. Michal Turošík, PhD., Katedra dejín štátu a práva, Právnická fakulta UMB v Banskej Bystrici
} 


\section{PRÁVNE ROZPRAVY ON-SCREEN II. - Sekcia súkromného práva}

online vedecká konferencia - 13. november 2020

ktoré boli dohodnuté alebo ich bolo možné očakávat'. Kupujúci však v prípade ak je kúpna zmluva realizovaná za prítomnosti oboch zmluvných strán mal „povinnost““ prezriet' si predmet kúpy. Nešlo tu o povinnost' v pravom zmysle slova, ale výkon zodpovednosti za zjavné faktické vady. V zmysle zásady caveat emptor totiž predávajúci nezodpovedal za zjavné vady, ktoré kupujúci mohol pri pozornom prezretí veci odhalit'. Zimmermann tu popisuje podobnú zásadu starého nemeckého práva ,,Augen auf, kauf ist Kauf. “2Kupujúci mal teda nakupovat' s „otvorenými očami“, čím by na seba preberal zodpovednost’ za zjavné faktické vady. Iná situácia samozrejme bola, ak sa jednalo o vadu skrytú.

Archaické právo v tomto prípade poznalo zodpovednost' predávajúceho len v jednom osobitnom prípade. Išlo o predaj pozemku, kedy predávajúci vo vyhlásení pri mancipácii (lex mancipio dicta), udal väčšiu výmeru pozemku ako bola v skutočnosti. V takomto prípade predávajúci zodpovedal za alikvotnú čiastku, ktorou bol pomer ceny pozemku k neexistujúcej ale udávanej výmere. Cicero vo svojom diele De officis dokonca hovorí o dvojnásobku tejto hodnoty ako sankcii za deliktuálne konani $^{3}$ v prípade ak predávajúci odmietol nárok kupujúceho a bol žalovaný s efektom kondemnačného rozsudku (infitiando lis crescit in duplum). V tomto prípade išlo o žalobu actio de modo agri. Tento prostriedok právnej ochrany sa objavuje aj v klasickom práve, podobne však ako samotná mancipácia sa prestal používat' v poklasickom období a v justiniánskom práve ho už nenájdeme.

Najstaršie formy zodpovednosti za faktické vady boli častokrát vnímané ako forma zvýšenej právnej istoty, kedy predávajúci nemal zodpovedat' len do hodnoty veci, ale prípadne až do jej dvojnásobku. Predat' vec s faktickou (prípadne aj právnou vadou) v sebe teda zahíňala akoby deliktuálnu zodpovednost'. Toto tvrdenie podkladáme skutočnost'ou, že pomerne často bola ku kúpnej zmluve pridávaná verbálna stipulácia, ktorou sa predávajúci pod sankciou zodpovednosti za všetok záujem kupujúceho zaväzoval k tomu, že vec má určité vlastnosti alebo naopak nemá vady. K tomu nám ponúka Ulpián fragment v dvadsiatej prvej knihe:

„Si ita quis stipulanti spondeat" sanum esse, furem non esse, vispellionem non esse" et cetera, inutilis stipulatio quibusdam videtur, quia si quis est in hac causa, impossibile est quod promittitur, si non est, frustra est. sed ego puto verius hanc stipulationem "furem non esse, vispellionem non esse, sanum esse" utilem esse: hoc enim continere, quod interest horum quid esse vel horum quid non esse. sed et si cui horum fuerit adiectum " praestari",

\footnotetext{
${ }^{2}$ ZIMMERMAN R: The law of obligations. Oxford. OXFORD UNIVERSITY PRESS, 1996, str. 307

${ }^{3}$ Cicero, De ofiicis, 3 XVI-65
} 


\section{PRÁVNE ROZPRAVY ON-SCREEN II. - Sekcia súkromného práva}

online vedecká konferencia - 13. november 2020

multo magis valere stipulationem: alioquin stipulatio quae ab aedilibus proponitur inutilis erit, quod utique nemo sanus probabit. “4

V tomto fragmente sa píše o predaji otroka, ktorý má byt' deklarovaný ako zdravý. Význam tohto fragmentu spočíva $\mathrm{v}$ akceptácii zodpovednosti konkrétnych vád prípadne vlastností, teda akejsi dodatočnej zodpovednosti vyplývajúcej zo stipulácie. Motívom pre uzatváranie takéhoto dodatočného kontraktu bolo, aby kupujúci mal väčšiu istotu v otázkach kvality predmetu kúpy. Išlo teda skutočne podl'a nášho názoru o zvýšenie právnej istoty kupujúceho. V období neskoršej republiky sa na tieto účely používala už prevažne len actio empti. Príkladom je Pompóniov text z devätnástej knihy:

„Si vas aliquod mihi vendideris et dixeris certam mensuram capere vel certum pondus habere, ex empto tecum agam, si minus praestes. sed si vas mihi vendidieris ita, ut adfirmares integrum, si id integrum non sit, etiam id, quod eo nomine perdiderim, praestabis mihi: si vero non id actum sit, ut integrum praestes, dolum malum dumtaxat praestare te debere. labeo contra putat et illud solum observandum, ut, nisi in contrarium id actum sit, omnimodo integrum praestari debeat: et est verum. quod et in locatis doliis praestandum sabinum respondisse minicius refert. "5

Pomponius v predloženom texte popisuje zodpovednost' za vlastnosti, ktoré boli deklarované vo vzt’ahu k predmetu kúpy a ktorých absencia môže viest' k použitiu žaloby actio empti. Touto žalobou sa môže žiadat' nielen alikvotná čiastka k nepomeru skutočných a deklarovaných vlastností, ale prípadne všetka škoda, ktorá takýmto dezinformovaním kupujúceho vznikne. Rimania tu apelovali na poctivý obchodný styk ako aj na vznik možnej sankcie ak dôjde k porušeniu zmluvy vplyvom odovzdania predmetu, ktorý nesplńa vlastnosti, ktoré mal a ktorých deklarácia mohla byt' významným faktorom motivácie kupujúceho uzavriet' tento kontrakt. Zimmermann tu dodáva, že na túto situáciu sa nebude vzt'ahovat' zásada caveat emptor, ktorej sa budeme venovat' nižšie. Zároveň ponúka prípad Ulpiánom popsovaný prípad:

„Iulianus libro quinto decimo inter eum, qui sciens quid aut ignorans vendidit, differentiam facit in condemnatione ex empto: ait enim, qui pecus morbosum aut tignum vitiosum vendidit, si quidem ignorans fecit, id tantum ex empto actione praestaturum, quanto minoris essem empturus, si id ita esse scissem: si vero sciens reticuit et emptorem decepit, omnia detrimenta, quae ex ea emptione emptor traxerit, praestaturum ei: sive igitur aedes vitio tigni corruerunt,

\footnotetext{
${ }^{4}$ D. $21,2,31$
}

${ }^{5}$ D. $19,1,6,4$ 


\section{PRÁVNE ROZPRAVY ON-SCREEN II. - Sekcia súkromného práva}

online vedecká konferencia - 13. november 2020

aedium aestimationem, sive pecora contagione morbosi pecoris perierunt, quod interfuit idonea venisse erit praestandum. "6

$\mathrm{Aj} \mathrm{z}$ tohto textu vyplýva jednoznačná povinnost' predávajúceho zodpovedat' za právne následky vady veci, ktorá nezodpovedá deklarovanému štandaru. Právnym následkom môže byt' vznik dodatočných náskladov, prípadne škody ktorá sa prejaví na strane kupujúceho, a ktorú bolo možné vymáhat' práve prostredníctvom actio empti.

Osobitnú právnu úpravu zodpovednosti za skryté vady priniesli edikty kurulských edilov, ktorí ich vydávali pri svojej činnosti správcov trhovej jurisdikcie. Išlo o zodpovednost' týkajúcu sa predovšetkým otrokov a t’ažných zvierat, ktoré boli mancipačnými vecami, čo je možno aj dôvod takéhoto výnimočného postupu. Edilovia boli magistráti, ktorí od roku 367 p.n.l. vykonávali dozor nad verejnými miestami, cestami či budovami. Okrem iného patrilo pod ich jurisdikciu aj výkon dohl’adu nad poctivým obchodným stykom. Ich úlohou bolo kontrolovat' správne miery, váhy, ceny obilia či trh s otrokmi. V rámci týchto právomocí im bola kurulským edilom ${ }^{7}$ priznaná obmedzená súdna právomoc.

Práve trh s otrokmi bol jedným z najvýznamnejších ekonomických pilierov trhového hospodárstva $\mathrm{v}$ Ríme. Predajcovia otrokov boli častokrát l'udia nevalnej povesti a preto obchod s nimi vyžadoval zvýšenú mieru opatrnosti, čo je zrejmé aj z Paulovho fragmentu:

„Proponitur actio ex hoc edicto in eum cuius maxima pars in venditione fuerit, quia plerumque venaliciarii ita societatem coeunt, ut quidquid agunt in commune videantur agere: aequum enim aedilibus visum est vel in unum ex his, cuius maior pars aut nulla parte minor esset, aedilicias actiones competere, ne cogeretur emptor cum multis litigare, quamvis actio ex empto cum singulis sit pro portione, qua socii fuerunt: nam id genus hominum ad lucrum potius vel turpiter faciendum pronius est. " 8

Aj z týchto dôvodov priznali kurulskí edilovia v druhom storočí p.n.l kupujúcej strane dva dodatočné právne prostriedky, ktoré mohli použit' podl'a svojho výberu' ${ }^{9}$. Išlo o žalobu actio redhibitoria s použitou formula arbitraria.

„Cum redhibetur mancipium, si quid ad emptorem pervenit vel culpa eius non pervenit, restitui oportet, non solum si ipse fructus percepit mercedesve a servo vel conductore servi accepit, sed etiam si a venditore fuerit idcirco consecutus, quod tardius ei hominem restituit:

\footnotetext{
${ }^{6}$ D. $19,1,13$

${ }^{7}$ Ich pomenovanie je odvodené od kresla na ktorom vykonávali ich úrad, sella curulis, ktoré sa vyznačovalo tým, že boli pokryté slonovinou

${ }^{8}$ D. $21,1,44,1$

${ }^{9}$ KASER M. , KNÜTEL R.: Römisches Privatrecht. München, C.H. BECK, 2008, str. 235
} 


\section{PRÁVNE ROZPRAVY ON-SCREEN II. - Sekcia súkromného práva}

online vedecká konferencia - 13. november 2020

sed et si a quovis alio possessore fructus accepit emptor, restituere eos debebit: sed et si quid fructuum nomine consecutus est, id praestet: item si legatum vel hereditas servo obvenerit. neque refert, potuerit haec consequi venditor an non potuerit, si servum non vendidisset: ponamus enim talem esse, qui capere aliquid ex testamento non potuerat: nihil haec res nocebit. pedius quidem etiam illud non putat esse spectandum, cuius contemplatione testator servum heredem scripserit vel ei legaverit, quia et si venditio remansisset, nihil haec res emptori proderat: et per contrarium, inquit, si contemplatione venditoris institutus proponeretur, tamen diceremus restituere emptorem non debere venditori, si nollet eum redhibere. "10

V tomto fragmente Ulpián popisuje kurulskými edilmi priznané právo pre kupujúceho, ktorý môže v lehote šiestich mesiacov žiadat' o navrátenie peňazí, za čo poskytne spätné plnenie predaja kúpy. Ide o možnost', ktorá v dnešnom ponímaní pripomína záručnú dobu, počas ktorej má predmet kúpy takú vadu, ktorá robí jeho užívanie nemožným, má kpujúci nárok na výmenu veci prípadne vrátenie peňazí. Priznaním týchto žalôb akoby rímske právo zavádzalo činnost’ou edilov ochranu trhového prostredia, ktorou sa dnešný obchod dodnes vyznačuje. V d’alšom fragmente Julián predstavuje inú možnost' kompenzácie faktickej vady: „Est in potestate emptoris intra sex menses, redhibitoria agere mallet an ea quae datur, quanti minoris homo cum veniret fuerit. nam posterior actio etiam redhibitionem continet, si tale vitium in homine est, ut eum ob id actor empturus non fuerit: quare vere dicetur eum, qui alterutra earum egerit, si altera postea agat, rei iudicatae exceptione summoveri. "11

V tomto prípade ide o faktickú vadu, ktorú síce predmet kúpy vykazuje, ale nerobí pre kupujúceho vec neužívatel’nou. V takom prípade môže kupujúci prostredníctvom žaloby actio quanti minoris žiadat' v priebehu jedného roka vrátenie pomernej časti ceny veci v pomere k vel'kosti vady, ktorú vec vykazuje. Ide akoby o uplatnenie nároku na primeranú zl'avu. Táto Žaloba sa využívala najmä pri obchode s otrokmi, čo deklaruje aj Ulpián, ktorý vo fragmente z dvadsiatejprvej knihy približuje edikt:

„, Aiunt aediles: " qui mancipia vendunt certiores faciant emptores, quid morbi vitiive cuique sit, quis fugitivus errove sit noxave solutus non sit: eademque omnia, cum ea mancipia venibunt, palam recte pronuntianto. quodsi mancipium adversus ea venisset, sive adversus quod dictum promissumve fuerit cum veniret, fuisset, quod eius praestari oportere dicetur: emptori omnibusque ad quos ea res pertinet iudicium dabimus, ut id mancipium redhibeatur.

\footnotetext{
${ }^{10}$ D. $21,1,23,9$

${ }^{11}$ D. $44,2,25,1$
} 


\section{PRÁVNE ROZPRAVY ON-SCREEN II. - Sekcia súkromného práva}

online vedecká konferencia - 13. november 2020

si quid autem post venditionem traditionemque deterius emptoris opera familiae procuratorisve eius factum erit, sive quid ex eo post venditionem natum adquisitum fuerit, et si quid aliud in venditione ei accesserit, sive quid ex ea re fructus pervenerit ad emptorem, ut ea omnia restituat. item si quas accessiones ipse praestiterit, ut recipiat. item si quod mancipium capitalem fraudem admiserit, mortis consciendae sibi causa quid fecerit, inve harenam depugnandi causa ad bestias intromissus fuerit, ea omnia in venditione pronuntianto: ex his enim causis iudicium dabimus. hoc amplius si quis adversus ea sciens dolo malo vendidisse dicetur, indicium dabimus".

Podl’a Ulpiána musia na základe ediktu kurulských edilov tí, ktorí predávajú otrokov, oboznámit' kupujúcich akou chrobou alebo akým nedostatkom predávaný otrok trpí, či má sklony k úteku. Tieto skutočnosti musia pri predaji pravdivo a verejne uviest'. Ak by totiž bol predaný otrok, napriek týmto ustanoveniam, bez toho, že by boli vyššie uvedené skutočnosti kupujúcemu známe, priznávajú mu edilovia žalobu na základe ktorej môže otroka vrátit’. Samozrejme musel kupujúci v prípade vrátenia otroka vrátit’ aj jeho prípadné prírastky. Rovnako ak by niekto konal proti vyššie uvedeným ustanoveniam edilov, bola mu nimi garantovaná rovnaká žaloba. Podmienkou pripustenia žalôb edilov, či už sa jednalo o actio redhibitoria alebo actio quanti minoris, bolo $\mathrm{v}$ prom rade to, že predávajúci vedome alebo nevedome neoznámil skutočnosti, ktoré boli vymenované v edikte, prípadne výslovne tvrdil, že predmet má niektoré vlastnosti (dictum promissere) alebo ich slúbil v stipulácii (promissum), či sa akokol'vek inak správal nedobromysel'ne teda so zlým úmyslom. Ako sa už spomínalo vyššie edikt predpisuje predávajúcemu, aby kupujúcemu oznámil choroby, nedostatky, určité charakterové vady, ale aj zat’aženie noxálnou zodpovednost'ou. Na zákalde toho nosili otroci , ktorí boli na predaj na krku štítok na ktorom bolo ich meno, národnost', vek ako aj prípadné zmienené nedostatky. Podl’a názoru tak dochádzalo k modifikácii vád zo skrytých na zjavné, čo samozrejme malo za následok vylúčenie zodpovednosti predávajúceho. Čo sa rozumelo pod chorobou bolo však nejednotné ako dodáva Kaser, ktorý poukazuje na sériu fragmeotv, ktoré dokazujú čo všetko nebolo považované za chorobu:

„Qui clavum habet, morbosus est: sed et polyposus. Eum, qui alterum oculum aut alteram maxillam maiorem habet, si recte iis utatur, sanum videri pedius scribit: ait enim inaequalitatem maxillarum oculorum brachiorum, si nihil ex ministerio praestando subtrahit, extra redhibitionem esse. sed et latus vel crus brevius potest adferre impedimentum: ergo et hic erit redhibendus. Si quis natura gutturosus sit aut oculos eminentes habeat, sanus videtur. 


\section{PRÁVNE ROZPRAVY ON-SCREEN II. - Sekcia súkromného práva}

online vedecká konferencia - 13. november 2020

Item sciendum est scaevam non esse morbosum vel vitiosum, praeterquam si inbecillitate dextrae validius sinistra utitur: sed hunc non scaevam, sed mancum esse. Is cui os oleat an sanus sit quaesitum est: trebatius ait non esse morbosum os alicui olere, veluti hircosum, strabonem: hoc enim ex illuvie oris accidere solere. si tamen ex corporis vitio id accidit, veluti quod iecur, quod pulmo aut aliud quid similiter dolet, morbosus est. "12

prípadov stavov alebo vád, ktoré sa pre tento prípad nepovažovali za chorobu ${ }^{13}$. Išlo napríklad o koktanie, krívanie, či pomočovanie sa alebo l'avorukost' prípadne tehotenstvo. $\mathrm{Na}$ druhej strane nám pramene ponúkajú aj definíciu toho, čo sa pre tento účel považuje za chorobu:

„Sed sciendum est morbum apud sabinum sic definitum esse habitum cuiusque corporis contra naturam, qui usum eius ad id facit deteriorem, cuius causa natura nobis eius corporis sanitatem dedit: id autem alias in toto corpore, alias in parte accidere ( namque totius corporis morbus est puta fvisis febris, partis veluti caecitas, licet homo itaque natus sit): vitiumque a morbo multum differre, ut puta si quis balbus sit, nam hunc vitiosum magis esse quam morbosum. ego puto aediles tollendae dubitationis gratia bis kata tou autou idem dixisse, ne qua dubitatio superesset. "14

Pre určenie toho, či niečo je alebo nie je choroba platila v zásade Labeova definícia obsiahnutá vo vyššie uvedenom fragmente. Podl'a nej sa za chorobu považuje neprirodzený stav tela, ktorý ovplyvní jeho použitel’nost'. Táto definícia platila ako smernica ${ }^{15}$. Za chorobu a zároveň vadu veci sa považovali chýbajúce končatiny, epilepsia, tuberkulóza, nemota, krátkozrakost', kastrácia a iné. Ako sme už naznačili vyššie pri ediktoch išlo o ochranu kupujúceho, môžeme povedat' že tu išlo o antickú formu ochrany spotrebitel'a. Ulpián to vysvetl'uje:

„Causa huius edicti proponendi est, ut occurratur fallaciis vendentium et emptoribus succurratur, quicumque decepti a venditoribus fuerint: dummodo sciamus venditorem, etiamsi ignoravit ea quae aediles praestari iubent, tamen teneri debere. nec est hoc iniquum: potuit enim ea nota habere venditor: neque enim interest emptoris, cur fallatur, ignorantia venditoris an calliditate. “

Ulpián tu prezentuje dôvody vydania ediktu poskytujúcom prezentovanú ochranu kupujúceho. Podl'a neho je hlavným význam vydania ediktu predchádzat' podvodom zo strany

\footnotetext{
${ }^{12}$ D. $21,1,121-4$

${ }^{13}$ KASER M. , KNÜTEL R.: Römisches Privatrecht. München, C.H. BECK, 2008, str. 235

${ }^{14}$ D. $21,1,1,7$

${ }^{15}$ HONSELL., H.: Von den aedilizischen Rechtsbehelfen zum modernen Sachmängelrecht, Kunkel, 1984, str. 53
} 


\section{PRÁVNE ROZPRAVY ON-SCREEN II. - Sekcia súkromného práva}

online vedecká konferencia - 13. november 2020

predávajúcich a poskytnutie pomoci kupujúcim, pričom zodpovednost' predávajúceho sa v niektorých prípadoch neobmedzuje tým, či o danej vade vedel alebo nie. Samozrejme podobne ako je tomu dnes, už v Ríme sa mnohí obchodníci snažili tieto ustanovenia obíst'. Typický príklad uvádza Paulus:

„Itaque sicut superius venditor de morbo vitiove et ceteris quae ibi comprehensa sunt praedicere iubetur, et praeterea in his causis non esse mancipium ut promittat praecipitur: ita et cum accedat alii rei homo, eadem et praedicere et promittere compellitur. quod non solum hoc casu intellegendum est, quo nominatim adicitur accessurum fundo hominem stichum, sed etiam si generaliter omnia mancipia quae in fundo sint accedant venditioni. "16

Jedným zo spôsobov pokusu o obchádzanie ochrany kupujúceho bol predaj otroka ako príslušenstva menejcennej veci. Práve proti takémuto konaniu vydali kurulskí edilovia osobitnú klauzulu na základe ktorej, sa pri takýchto pokusosch mali uplatnit' rovnaké ustanovenia ako boli uplatňované pri bežnom predaji otrokov. Pedius vo nižšie uvedenom fragmente hovorí o týchto ustanoveniach ako takých, ktoré dokonca chránia l'udskú dôstojnost' (propter dignitatem hominum).

„Iustissime aediles noluerunt hominem ei rei quae minoris esset accedere, ne qua fraus aut edicto aut iure civili fieret: ut ait pedius, propter dignitatem hominum: alioquin eandem rationem fuisse et in ceteris rebus: ridiculum namque esse tunicae fundum accedere. ceterum hominis venditioni quidvis adicere licet: nam et plerumque plus in peculio est quam in servo, et nonnumquam vicarius qui accedit pluris est quam is servus qui venit. "17

Dôležitou otázkou na ktorú musíme v tejto publikácii odpovedat' je, či sa mohol kupujúci dovolávat' dvojitej právnej ochrany. Gaius sa v tomto smere vyjadruje nejednoznačne:

„Si venditor de his quae edicto aedilium continentur non caveat, pollicentur adversus eum redhibendi iudicium intra duos menses vel quanti emptoris intersit intra sex menses. "18

V tomto fragmente Gaius píše, že ak nie je predávajúci viazaný stipuláciou, edilovia poskytujú (kupujúcemu) pre tento prípad už spomínané dve žaloby. Podl’a Kasera však edikt o ochrane kupujúceho poskytuje dvojakú právnu ochranu ${ }^{19}$. V prvom prípade sa jedná o žaloby, ktoré kurulskí edilovia garantovali prostredníctvom ediktu ak predávajúci neoboznámil kupujúceho s vlastnost’ami o ktorých ho upovedomit’ mal. Ako druhú formu

\footnotetext{
${ }^{16}$ D. $21,1,32$

${ }^{17}$ D. $21,1,44$

${ }^{18}$ D. $21,1,28$

${ }^{19}$ KASER M. , KNÜTEL R.: Römisches Privatrecht. München, C.H. BECK, 2008, str. 236
} 


\section{PRÁVNE ROZPRAVY ON-SCREEN II. - Sekcia súkromného práva}

online vedecká konferencia - 13. november 2020

právnej ochrany priznávajú edilovia kupujúcemu právo požadovat' od predávajúceho uzavretie garančnej stipulácie, v ktorej výslovne slúbi, že vec nemá vady o ktorých hovorí edikt. V takomto prípade môže kupujúci v prípade sporovej situácie žalovat' predávajúceho pomocou actio ex stipulatu a požadovat' všetok svoj záujem. Jakab naproti tomu zastáva názor, že nešlo o dvojitú právnu ochranu, teda stipulácia sa nepoužívala popri žalobách redhibitoria a quanti minoris. Podl'a neho slúžila takáto garančná stipulácia len ako rpcesný prostriedok na to, aby bol právne vyjadrený nárok kupujúceho a povinnost' predávajúceho, ak predávajúci porušil svoju informačnú povinnost', ktorá mu vyplýva z ediktu kurulských edilov. Až ked' chcel skutočne kupujúci na zákalde vady predanej veci žalovat', uložil edil predávajúcemu povinnost' stipulovat' nárok kupujúceho na základe ediktu, nakol'ko pôvodne právomoc edilov nezahŕňala kompetenciu bezprostredne začat' procesné konanie. Ak sa vtedy predávajúci zdráhal stipulovat', prišla na rad podl'a Jakaba možnost', ktorú Gaius popisuje v D.21,1,28 (uvádzaný vyššie), a to, že mu edilovia garantovali použitie actio redhibitoria alebo actio quanti minoris ${ }^{20}$. Samozrejme v popisovaných lehotách dvoch alebo šiestich mesiacov. Žiada sa pridat' ešte názor Kupischa, ktorý Jakabovi a kaserovi oponuje. Ani podl’a neho sa nejednalo o systém dvojitej právnej ochrany kupujúceho. Má za to, že zmluvné strany sa v prípade takejto kúpy mohli dohodnút' ako budú v prípade zodpovednosti za vady postupovat'. Kupisch popisuje tri možnosti. Prvou je situácia o ktorej sa zmieňuje Pomponius: „Simplariarum venditionum causa ne sit redhibitio, in usu est. “21

Tu sa zmluvné strany dohodnú na zodpovednost' za faktické vady veci úplne vylúčit' (simplaria venditio). Ide o tzv. jednoduchú kúpu, pri ktorej sa samozrejme vylúčenie zodpovednosti za faktické vady v zásade prejavilo aj na kúpnej cene. Druhou možnost'ou bolo uzavretie štandarnej zmluvy bez vylúčenia zodpovednosti, ale aj bez uzavretia dodatočnej garančnej stipulácie. Tret'ou možnost'ou bolo uzavretie zmluvy, posilnenej uzavretím stipulácie, odporúčanej edilmi, čím by sa v skutočnosti zdvojnásobila právna ochrana kupujúceho a najmä by sa mu v prípade faktických vád veci priznal nárok aj na náhradu škody ${ }^{22}$. Záverom k téme kurulskej „ochrane spotrebitel'a“ uvádzame fragment $\mathrm{z}$ dvadsiatej prvej knihy, ktorý pojednáva o d’alších prípustných lehotách pre garanciu spomínaných dvoch žalôb.

\footnotetext{
${ }^{20}$ JAKAB E.: Praedicere und cavere beim Marktkauf, 1999, str. 12

${ }^{21}$ D. $21,1,48,8$

${ }^{22}$ KUPISCH, B: Roemische Sachmängelhaftung: Ein Beispiel fuer die oekonom. Analyse des Rechts, TR 70, 2002 , str. 21
} 


\section{PRÁVNE ROZPRAVY ON-SCREEN II. - Sekcia súkromného práva}

online vedecká konferencia - 13. november 2020

„Aediles aiunt: " qui iumenta vendunt, palam recte dicunto, quid in quoque eorum morbi vitique sit, utique optime ornata vendendi causa fuerint, ita emptoribus tradentur. si quid ita factum non erit, de ornamentis restituendis iumentisve ornamentorum nomine redhibendis inminoris cum venirent fuerint, in anno iudicium dabimus. si iumenta paria simul venierint et alterum in ea causa fuerit, ut redhiberi debeat, iudicium dabimus, quo utrumque redhibeatur". ${ }^{23}$

Podobne ako pri otrokoch predpisoval edikt predávajúcemu aj v prípade d’alšej mancipačnej veci, ktorou boli t’ažné zvieratá, oznamovaciu povinnost' vo vzt’ahu k určitým nedostatkom či naopak vlastnostiam. Na základe uvedeného fragmentu však vieme, že ochranná lehota kupujúceho tu bola predížená. Ten totiž mohol podat’ žalobu redhibitoria $\mathrm{v}$ priebehu šiestich mesiacov a žalobu quanti minoris dokonca až v priebehu jedného roka.

\section{ZOZNAM POUŽITEJ LITERATÚRY A PRAMEŇOV}

D. $19,1,13$

D. $19,1,6,4$

D. $21,1,121-4$

D. $21,1,32$

D. $21,1,44,1$

D. $21,2,31$

D. $21,1,28$

D. $21,1,1,7$

D. $21,1,44$

D. $21,1,48,8$

D. $44,2,25,1$

KUPISCH, B: Roemische Sachmängelhaftung: Ein Beispiel fuer die oekonom. Analyse des Rechts, TR 70, 2002

KASER M. , KNÜTEL R.: Römisches Privatrecht. München, C.H. BECK, 2008

HONSELL., H.: Von den aedilizischen Rechtsbehelfen zum modernen Sachmängelrecht, Kunkel, 1984

\footnotetext{
${ }^{23}$ D. $21,1,38$
} 
PRÁVNE ROZPRAVY ON-SCREEN II. - Sekcia súkromného práva

online vedecká konferencia - 13. november 2020

KINCL J., URFUS V., SKŘEJPEK M.: Ǩímské právo.Praha: CH.BECK, 1995

JAKAB E.: Praedicere und cavere beim Marktkauf, 1999

SKŘEJPEK M.: Prameny ř́mského práva. Praha. LEXIS NEXIS, 2004

ZIMMERMAN R: The law of obligations. Oxford. OXFORD UNIVERSITY PRESS, 1996 